\title{
Bibliography
}

\section{Primary sources}

Anon., 'A Sermon against Miracle-Plays', in Reliquice antiquœ: Scraps from Ancient Manuscripts, ed. Thomas Wright and James Orchard Halliwell, 2 vols (London: William Pickering, 1841), Vol. I, pp. 42-57

Anon., The Three Parnassus Plays (1598-1601), ed. J. B. Leishman (London: Ivor Nicholson \& Watson, 1949)

Apuleius, The Golden Ass, trans. W. Adlington (1566), rev. and intro. S. Gaselee (London: William Heinemann, 1965 [1915])

Ariosto, Ludovico, Orlando furioso, ed. Lanfranco Caretti (Milano: Riccardo Ricciardi, 1954)

Ariosto, Ludovico, Orlando Furioso, trans. Sir John Harington (1591), ed. Robert McNulty (Oxford: Clarendon Press, 1972)

Aristotle, Problemata, trans. E. S. Forster (Oxford: Clarendon Press, 1927). Retrieved from Internet Archive, https://archive.org/stream/ worksofaristotle07arisuoft/worksofaristotle07arisuoft_djvu.txt (accessed May 2019)

Aristotle, Poetics, trans. M. E. Hubbard, in Ancient Literary Criticism: The Principal Texts in New Translations, ed. D. A. Russell and M. Winterbottom (Oxford: Oxford University Press, 1972), pp. 85-132

Ascham, Roger, The Scholemaster (Menston: Scolar Press, 1967 [1570]) Ashmole, Elias, The Institution, Laws and Ceremonies of the Most Noble Order of the Garter (London, 1672)

Augustine of Hippo, St, The City of God against the Pagans, ed. R. W. Dyson (Cambridge: Cambridge University Press, 1998)

Barclay, Alexander, The Lyfe of St George, ed. William Nelson, EETS, o.s. 230 (London: Oxford University Press, 1955)

Basil of Caesarea, St, St Basil: Letters and Selected Works (1895), trans. Blomfield Jackson, Vol. VIII of Nicene and Post-Nicene Fathers, 
second series, 14 vols, ed. Philip Schaff and Henry Wace (Buffalo, NY: Christian Literature, 1886-1900)

Bevington, David, ed., Medieval Drama (Boston, MA: Houghton Mifflin, 1975)

Boccaccio, Giovanni, The Decameron, 2 vols (London: J. M. Dent, 1963 [1930])

The Book of Common Prayer 1559: The Elizabethan Prayer Book, ed. John

E. Booty (Charlottesville: University of Virginia Press, 2005)

Boorde, Andrew, see Scoggins iests

Brewer, Derek, ed., Chaucer: The Critical Heritage, 2 vols (London: Routledge \& Kegan Paul, 1978)

Brewer, Derek, ed., Medieval Comic Tales, 2nd edn (Cambridge: D. S. Brewer, 1996)

Bullinger, Heinrich, The christen state of matrimonye, trans. Miles Coverdale (Amsterdam: Theatrum Orbis Terrarum, 1974 [1541])

Bunyan, John, The Pilgrim's Progress, ed. Roger Sharrock (London: Penguin, 1987)

Burton, Robert, The Anatomy of Melancholy, ed. Holbrook Jackson, 3 vols (London: J. M. Dent, 1961 [1932])

Byron, Lord [George Gordon], Don Juan, ed. T. G. Steffan et al. (London: Penguin, 1982)

Calvin, John. Commentaries on the Book of the Prophet Jeremiah and the Lamentations, trans. and ed. Revd John Owen, 5 vols (Edinburgh: Calvin Translation Society, 1850-5)

Calvin, John, Institutes of the Christian Religion, trans. Henry Beveridge, 2 vols (Edinburgh: T. \& T. Clarke, 1863)

Castelvetro, Lodovico, Castelvetro on the Art of Poetry: An Abridged Translation of Lodovico Castelvetro's 'Poetica d'aristotele vulgarizzata et sposta', trans, intro. and notes Andrew Bongiorno, Medieval and Renaissance Texts and Studies, Vol. 29 (Binghamton: State University of New York Press, 1984)

Castiglione, Baldassare, The Book of the Courtier, trans. Sir Thomas Hoby (London: J. M. Dent, 1974 [1928])

Cervantes, Miguel de, The History of Don Quixote of the Mancha, trans.

Thomas Shelton, 2 vols (London: Navarre Society, 1923 [1612-20])

Chaucer, Geoffrey, The Tales of Canterbury, ed. Robert A. Pratt (Boston, MA: Houghton Mifflin, 1966)

Chaucer, Geoffrey, The Riverside Chaucer, ed. Larry D. Benson, 3rd edn (Oxford: Oxford University Press, 1988)

Chaloner, Sir Thomas, see Erasmus 
Chapman, George, see Homer

Cicero, De oratore, trans. E. W. Sutton and H. Rackham, rev. edn, 2 vols (London: Heinemann, 1959-60 [1948])

Cummings, R. M., ed., Spenser: The Critical Heritage (London: Routledge \& Kegan Paul, 1971)

Davenant, William, Gondibert (1651), ed. David F. Gladish (Oxford: Clarendon Press, 1971)

Davies, Sir John, The Gullinge Sonnets (c. 1596), in The Complete Poems of Sir John Davies, ed. Revd Alexander B. Grosart, 2 vols (London: Chatto and Windus, 1876), Vol. II, pp. 55-62; etext (created by Anniina Jokinen) in Luminarium Editions, www.luminarium.org/ editions/gullingsonnets.htm (accessed May 2019)

Dives and Pauper, ed. Priscilla Heath Barnum, 3 vols, EETS, o.s. 275, 280, 323 (London: Oxford University Press, 1976-2004)

Donne, John, Donne's Sermons: Selected Passages, ed. Logan Pearsall Smith (Oxford: Clarendon Press, 1959 [1919])

Du Bellay, Joachim, Defence and Illustration of the French Language, trans. Gladys M. Turquet (London: J. M. Dent, 1939)

Du Bellay, Joachim, La Deffence et illustration de la langue françoyse, ed. Jean-Charles Monferran, Textes littéraires français, 543 (Geneva: Droz, 2001)

Erasmus, Desiderius, A ryght frutefull epystle, deuysed by the moste excellent clerke Erasmns [sic], in laude and prayse of matrymony, trans. Richard Taverner (London: Robert Redman, 1536)

Erasmus, Desiderius, The Praise of Folie, trans. Sir Thomas Chaloner (1549), ed. Clarence H. Miller, EETS, o.s. 257 (London: Oxford University Press, 1965)

Erasmus, Desiderius, 'Praise of Folly' and Letter to Martin Dorp, 1515, trans. Betty Radice, intro. and notes A. H. T. Levi (London: Penguin, 1971)

Erasmus, Desiderius, Enchiridion militis christiani, trans. Charles Fantazzi, in Collected Works of Erasmus, Vol. LXVI: Spiritualia, ed. John W. O’Malley (Toronto: University of Toronto Press, 1988), pp. $1-127$

Foxe, John, The Unabridged Acts and Monuments Online (Sheffield: Digital Humanities Institute, 2011), 1570 edn

Garret, Martin, ed., Sidney: The Critical Heritage (London: Routledge, 1996)

Gascoigne, George, The Complete Works of George Gascoigne, ed. John W. Cunliffe, 2 vols (Cambridge: Cambridge University Press, 1907-10) 
Gascoigne, George, A Hundreth Sundrie Flowres, ed. G. W. Pigman III (Oxford: Clarendon Press, 2000)

Gower, John, Confessio Amantis, ed. Russell A. Peck (Toronto: University of Toronto Press, 1997 [1980])

Greenham, Richard, The workes of the reuerend and faithfull seruant of Iesus Christ M. Richard Greenham, minister and preacher of the Word of God (London, 1601)

Harington, John, see Ariosto, Ludovico

Hazlitt, William, Lectures on the English Comic Writers (London: Taylor and Hessey, 1819), pp. 1-53

Hobbes, Thomas, The English Works of Thomas Hobbes, ed. Sir William Molesworth, Bart, 11 vols (London: John Bohn, 1966)

Hobbes, Thomas, 'Hobbes's Answer to the Preface' (1650), in William Davenant, Gondibert (1651), ed. David F. Gladish (Oxford: Clarendon Press, 1971), pp. 45-55

Homer, Chapman's Homer: 'The Iliad', 'The Odyssey', and the Lesser Homerica, trans. George Chapman, ed. Allardyce Nicoll, 2nd edn, 2 vols, Bollingen Series, 41 (Princeton: Princeton University Press, 1956) Homer, The 'Iliad' of Homer, trans. Alexander Pope, ed. Maynard Mack, 2 vols (London: Methuen, 1967)

Homer, Homeric Hymns, Homeric Apocrypha, Lives of Homer, trans. and ed. Martin L. West (Cambridge, MA: Harvard University Press, 2003) Hooper, John, Early Writings of Hooper, ed. Samuel Carr, Parker Society Publications, 20 (Cambridge: Cambridge University Press, 1843)

Horace, The Art of Poetry, trans. D. A. Russell, in Ancient Literary Criticism: The Principal Texts in New Translations, ed. D. A. Russell and M. Winterbottom (Oxford: Oxford University Press, 1972), pp. 279-91 Hurd, Richard, Letters on Chivalry and Romance (1762), Vol. III of Spenser's 'Faerie Queene': Warton's Observations and Hurd's Letters, ed. David Fairer, 3 vols (London: Routledge, 2001)

Hurtado de Mendoza, Diego, Lazarillo de Tormes, trans. David Rowland (London: Abell Ieffes, 1586)

Jerome, St, Select Letters of St Jerome, trans. F. A. Wright (London: Heinemann, 1933)

Johnson, Samuel, 'Preface to Shakespeare' (1765), in Johnson on Shakespeare, ed. Arthur Sherbo, Vols VII-VIII of The Yale Edition of the Works of Samuel Johnson, 23 vols (New Haven: Yale University Press, 1968), Vol. VII, pp. 59-113

Jonson, Ben, 'The Alchemist' and Other Plays, ed. and intro. Gordon Campbell (Oxford: Oxford University Press, 1995) 
Joubert, Laurent, Traité $d v$ ris, contenant son essance, ses causes, et mervelheus effais, curieusemant recerchés, raisonnés \& observés (Paris, 1579)

Joubert, Laurent, Treatise on Laughter, trans. Gregory David de Rocher (Tuscaloosa, AL: University of Alabama Press, 1980)

Langland, William, The vision of Pierce Plowman, nowe the seconde time imprinted, ed. Robert Crowley (London: R. Grafton, 1550)

Langland, William, Piers the Ploughman, trans. and intro. J. F. Goodridge (Harmondsworth: Penguin, 1966)

Latimer, Hugh, Sermons of Latimer, ed. George Elwes Corrie, Parker Society Publications, 27 (Cambridge: Cambridge University Press, 1844)

Longinus, On Sublimity, trans. D. A. Russell, in Ancient Literary Criticism: The Principal Texts in New Translations, ed. D. A. Russell and M. Winterbottom (Oxford: Oxford University Press, 1972), pp. $460-503$

Nashe, Thomas, The Works of Thomas Nashe, ed. Ronald B. McKerrow (Oxford: Basil Blackwell, 1958)

Malory, Thomas, The Works of Sir Thomas Malory, ed. Eugène Vinaver, 2nd edn, 3 vols (Oxford: Clarendon Press, 1973 [1967])

Mantuan, see Barclay, Alexander

Marx, Karl, The Ethnological Notebooks of Karl Marx, ed. Lawrence Krader, 2nd edn (Assen: Van Gorcum, 1974)

Milton, John, Complete Prose Works of John Milton, ed. Don Marion Wolfe, 8 vols (New Haven: Yale University Press, 1953-82)

Milton, John, Paradise Lost, ed. Christopher Ricks (London: Penguin, 1989)

More, Thomas, A Dialogue of Comfort against Tribulation, ed. Louis L. Martz and Frank Manley (1976), Vol. XII of The Yale Edition of the Complete Works of St Thomas More, 15 vols (New Haven: Yale University Press, 1963-97)

Mulcaster, Richard, Positions wherein those primitiue circvmstances be examined, which are necessarie for the training $v p$ of children, either for skill in their booke, or health in their bodie (London: Thomas Chard, 1581)

Munday, Anthony, A Second and Third Blast of Retrait from Plaies and Theatres (New York: Garland, 1973 [1580])

Ovid, Metamorphoses, trans. A. D. Melville, intro. and notes E. J. Kenney (Oxford: Oxford University Press, 1987) 
Parker, Matthew, Correspondence of Parker, ed. John Bruce and Thomas Thomason Perowne, Parker Society Publications, 33 (Cambridge: Cambridge University Press, 1853)

Perkins, William, A Direction for the Governement of the Tongve According to Gods Word, in The Workes of That Famovs and VVorthie Minister of Christ, in the Vniversitie of Cambridge, M. W. Perkins, 3 vols (London, 1608-37), Vol. I, pp. 439-51

Plato, The Republic, trans. Tom Griffith, ed. G. R. F. Ferrari (Cambridge: Cambridge University Press, 2008 [2000])

Pope, Alexander, The Twickenham Edition of the Poems of Alexander Pope, ed. Norman Ault and John Butt, 11 vols (London: Methuen, 1953-69)

Prudentius, Prudentius, with an English Translation, ed. and trans. H. J. Thomson, 2 vols (Cambridge, MA: Harvard University Press, 1949)

Puttenham, George, The Arte of English Poesie (1589), in Elizabethan

Critical Essays, ed. G. Gregory Smith, 2 vols (Oxford: Oxford University Press, 1904), Vol. II, 1-193

Quintilian, Institutio oratoria, trans. H. E. Butler, 4 vols (London: Heinemann, 1953 [1921-2])

Rabelais, François, The Complete Works, trans. Sir Thomas Urquhart and Peter Motteux, 2 vols (London: John Lane, 1927)

Robinson, Hastings, trans. and ed., The Zurich Letters, 2 vols, Parker Society Publications, 50-1 (Cambridge: Cambridge University Press, 1842-5)

Russell, D. A., and M. Winterbottom, eds, Ancient Literary Criticism: The Principal Texts in New Translations (Oxford: Oxford University Press, 1972)

Schopenhauer, Arthur, The World as Will and Representation, trans. E. F. J. Payne, 2 vols (New York: Dover, 1969)

Scoggins iests, ed. Andrew Boorde(?) (London: Francis Williams, 1626) Shakespeare, William, The Riverside Shakespeare, ed. Herschel Baker et al., 2nd edn (New York: Houghton Mifflin, 1997)

Sidney, Sir Philip, The Old Arcadia, ed. and intro. Katherine DuncanJones (Oxford: Oxford University Press, 1999)

Sidney, Sir Philip, The Defence of Poesy, in Sidney's 'The Defence of Poesy' and Selected Renaissance Literary Criticism, ed. and intro. Gavin Alexander (London: Penguin, 2004)

Smith, G. Gregory, ed., 'The Spectator', by Addison, Steele and others, 8 vols (London: J. M. Dent, 1897) 
Smith, G. Gregory, ed., Elizabethan Critical Essays, 2 vols (Oxford: Oxford University Press, 1904)

Smith, Henry, A preparatiue to mariage (London: Thomas Man, 1591)

Spenser, Edmund, The Works of Edmund Spenser: A Variorum Edition, ed.

Edwin Greenlaw et al., 11 vols (Baltimore: Johns Hopkins University Press, 1932-57)

Spenser, Edmund, The Faerie Queene, ed. A. C. Hamilton (London: Longman, 1995 [1977])

Spenser, Edmund, The Yale Edition of the Shorter Poems of Edmund Spenser, ed. William A. Oram, Einar Bjorvand, Ronald Bond, Thomas H. Cain, Alexander Dunlop, and Richard Schell (New Haven: Yale University Press, 1989)

Spenser, Edmund, The Faerie Qveene, ed. A. C. Hamilton, Hiroshi

Yamashita, and Toshiyuki Suzuki (Harlow: Pearson Education, 2001)

Spenser, Edmund, The Faerie Queene, Book I, ed. and intro. Carol Kaske (Indianapolis: Hackett, 2006)

Spenser, Edmund, The Faerie Queene, Books III and IV, ed. Dorothy Stephens (Indianapolis: Hackett, 2006)

Spenser, Edmund, 'The Faerie Queene': Book Six and the Mutabilitie

Cantos, ed. Andrew Hadfield and Abraham Stoll (Indianapolis: Hackett, 2007)

Statius, Publius Papinius, Statius, with an English Translation, trans. J. H. Mozley, 2 vols (Cambridge, MA: Harvard University Press, 1967 [1928])

Stubbes, Phillip, Anatomie of Abuses (1583), ed. Frederick J. Furnivall (Vaduz: Kraus Reprint, 1965 [1877-9])

Tasso, Torquato, Discorsi del poema eroico, in Prose, ed. Ettore Mazzali (Milan: Riccardo Ricciardi, 1959)

Tasso, Torquato, Discourses on the Heroic Poem, trans. Mariella Cavalchini and Irene Samuel (Oxford: Clarendon Press, 1973)

Taverner, Richard, see Erasmus, Desiderius

Vickers, Brian, ed., English Renaissance Literary Criticism (Oxford: Clarendon Press, 1999)

Vida, Marco Girolamo, The 'De arte poetica' of Marco Girolamo Vida (1517, 1527), trans. and ed. Ralph G. Williams (New York: Columbia University Press, 1976)

Viret, Pierre, The Christian Disputations, trans. John Brooke (London: Thomas East, 1579)

Virgil, Virgil, with an English Translation, trans. H. Rushton Fairclough, rev. edn, 2 vols (London: Heinemann, 1950 [1934]) 
Voragine, Jacobus de, The Golden Legend, trans. William Granger Ryan, 2 vols (Princeton: Princeton University Press, 1993)

Webbe, William, A Discourse of English Poetrie (1586), in Elizabethan Critical Essays, ed. G. Gregory Smith, 2 vols (Oxford: Oxford University Press, 1904), Vol. I, 226-302

Wilson, Thomas, Wilson's 'Arte of Rhetorique' (1560), ed. G. H. Mair (Oxford: Clarendon Press, 1909)

Zall, P. M., ed., 'A Hundred Merry Tales' and Other English Jestbooks of the Fifteenth and Sixteenth Centuries (Lincoln: University of Nebraska Press, 1963)

\section{Secondary sources}

Adamson, Sylvia, 'Literary Language', in The Cambridge History of the English Language, Vol. III: 1476-1776, ed. Roger Lass (Cambridge: Cambridge University Press, 1999), pp. 539-653

Adelman, Janet, 'Revaluing the Body in The Faerie Queene I', Hugh Maclean Memorial Lecture, SR, 36 (2005), 15-25

Allen, Don Cameron, Image and Meaning (Baltimore: Johns Hopkins University Press, 1968)

Anderson, Judith H., "In liuing colours and right hew": The Queen of Spenser's Central Books', in Poetic Traditions of the English Renaissance, ed. Maynard Mack and George deForest Lord (New Haven: Yale University Press, 1982), pp. 47-66

Anderson, Judith H., "A Gentle Knight was pricking on the plaine": The Chaucerian Connection', ELR, 15 (1985), 166-74

Anderson, Judith H., 'Arthur, Argante, and the Ideal Vision: An Exercise in Speculation and Parody', in The Passing of Arthur: New Essays in Arthurian Tradition, ed. Christopher Baswell and William Sharpe (New York: Garland, 1988), pp. 193-206

Anderson, Judith H., 'The "couert vele": Chaucer, Spenser, and Venus', ELR, 24 (1994), 638-59

Anderson, Judith H., Spenser's Narrative Figuration of Women in 'The Faerie Queene' (Kalamazoo: Medieval Institute Publications, 2017)

Aston, Margaret, England's Iconoclasts, Vol. I: Laws against Images (Oxford: Clarendon Press, 1988)

Auerbach, Erich, Mimesis: The Representation of Reality in Western Literature, trans. Willard R. Trask (Princeton: Princeton University Press, 1991 [1953]) 
Baker, David J., 'Spenser and Politics', in The Oxford Handbook of Edmund Spenser, ed. Richard A. McCabe (Oxford: Oxford University Press, 2010), pp. 48-64

Bakhtin, Mikhail, The Dialogic Imagination: Four Essays, trans. Caryl Emerson and Michael Holquist, ed. Michael Holquist (Austin: University of Texas Press, 1981)

Bakhtin, Mikhail, Rabelais and His World, trans. Hélène Iswolsky (Bloomington: Indiana University Press, 1984)

Barasch, Frances K., 'Definitions: Renaissance, Baroque, Grotesque Construction and Deconstruction', MLS, 13 (1983), 60-7

Beard, Mary, 'Ha Ha: What Made the Greeks Laugh? The Funny, the Peculiar, and a Possible Ancestor of Monty Python's Parrot', TLS (February 2009), 3-5

Bell, Bernard W., 'The Comic Realism of Una's Dwarf', Massachusetts Studies in English, 1 (1968), 111-18

Bennett, J. W., The Evolution of 'The Faerie Queene' (New York: Burt Franklin, 1960)

Benson, Larry D., 'The "Queynte" Punnings of Chaucer's Critics', SAC, 1 (1984), 23-47

Berger, Harry, Jr, Revisionary Play: Studies in the Spenserian Dynamics (Berkeley: University of California Press, 1988)

Berger, Harry, Jr, "Kidnapped Romance": Discourse in The Faerie Queene', in Unfolded Tales: Essays on Renaissance Romance, ed. George M. Logan and Gordon Teskey (Ithaca: Cornell University Press, 1989), pp. 208-56

Berger, Harry, Jr, 'Displacing Autophobia in Faerie Queene I: Ethics, Gender, and Oppositional Reading in the Spenserian Text', ELR, 28 (1998), 163-82

Berger, Harry, Jr, 'Sexual and Religious Politics in Book I of Spenser's Faerie Queene', ELR, 34 (2004), 201-42

Berleth, Richard J., 'Heavens Favourable and Free: Belphoebe's Nativity in The Faerie Queene', ELH, 40 (1973), 479-500

Berry, Craig A., 'Borrowed Armor/Free Grace: The Quest for Authority in The Faerie Queene I and Chaucer's "Tale of Sir Thopas"', SP, 91 (1994), 136-66

Berry, Craig A., "'Sundrie Doubts": Vulnerable Understanding and Dubious Origins in Spenser's Continuation of "The Squire's Tale", in Refiguring Chaucer in the Renaissance, ed. Theresa M. Krier (Gainesville: University Press of Florida, 1998), pp. 106-27 
Bettelheim, Bruno, The Uses of Enchantment: The Meaning and Importance of Fairy Tales (London: Thames and Hudson, 1976)

Betts, Hannah, 'The Pornographic Blazon, 1588-1603', in Dissing Elizabeth: Negative Representations of Gloriana, ed. Julia M. Walker (Durham, NC: Duke University Press, 1998), pp. 153-84

Bieman, Elizabeth, "'Sometimes I ... mask in myrth lyke to a Comedy": Spenser's Amoretti', SSt, 4 (1984), 131-41

Blackburn, William, 'Spenser's Merlin', Rene R, 4 (1980), 179-98

Blank, Paula, Broken English: Dialects and the Politics of Language in English Writings (London and New York: Routledge, 1996)

Bliss, Lee, 'Pastiche, Burlesque, Tragicomedy', in The Cambridge Companion to English Renaissance Drama, ed. A. R. Braunmuller and Michael Hattaway, 2nd edn (Cambridge: Cambridge University Press, 2003), pp. 228-53

Booth, Wayne, A Rhetoric of Irony (Chicago: University of Chicago Press, 1974)

Borris, Kenneth, Allegory and Epic in English Renaissance Literature: Heroic Form in Sidney, Spenser, and Milton (Cambridge: Cambridge University Press, 2000)

Bowers, R. H., 'Chaucer's Troilus as an Elizabethan "Wanton Book"', NQ, 7 (1960), 370-1

Brewer, Derek, ed., Chaucer: The Critical Heritage (1978), see under 'Primary sources'

Brewer, Derek, 'Comedy and Tragedy in Troilus and Criseyde', in The European Tragedy of Troilus, ed. Piero Boitani (Oxford: Clarendon Press, 1989), pp. 95-109

Brewer, Derek, ed., Medieval Comic Tales (1996), see under 'Primary sources'

Brewer, Derek, 'Prose Jest-Books Mainly in the Sixteenth to Eighteenth Centuries in England', in A Cultural History of Humour: From Antiquity to the Present Day, ed. Jan Bremmer and Herman Roodenburg (Cambridge: Polity Press, 1997), pp. 90-111

Briggs, Julia, This Stage-Play World: Texts and Contexts, 1580-1625 (Oxford: Oxford University Press, 1997)

Broich, Ulrich, The Eighteenth-Century Mock-Heroic Poem, trans. David Henry Wilson (Cambridge: Cambridge University Press, 1990)

Burke, Charles B., 'Humour in Spenser', NQ, 166 (1934), 113-15

Burke, Charles B., 'The “Sage and Serious” Spenser', NQ, 175 (1938), 457-8 Burrow, Colin, Edmund Spenser (Plymouth: Northcote House, 1996) 
Burrow, J. A., Ricardian Poetry: Chaucer, Gower, Langland and the 'Gawain' Poet (London: Routledge \& Kegan Paul, 1971)

Burrow, J. A., " "Sir Thopas" in the Sixteenth Century', in Middle English Studies Presented to Norman Davis, ed. Douglas Gray and E. G. Stanley (Oxford: Clarendon Press, 1983), pp. 69-91

Busby, Keith, and Roger Dalrymple, eds, Arthurian Literature XIX:

Comedy in Arthurian Literature (Cambridge: D. S. Brewer, 2003)

Butler, Chris, "Pricking" and Ambiguity at the Start of The Faerie Queene', NQ, 253 (2008): 159-61

Callaghan, Dympna, 'Comedy and Epyllion in Post-Reformation England', Shakespeare Survey, 56 (2003), 27-38

Camille, Michael, Image on the Edge: The Margins of Medieval Art (London: Reaktion, 1992)

Campana, Joseph, 'Letters (1580)', in The Oxford Handbook of Edmund Spenser, ed. Richard A. McCabe (Oxford: Oxford University Press, 2010), pp. 178-97

Carroll, D. Allen, 'The Meaning of "E. K."', SSt, 20 (2005), 169-81

Carver, Robert H. F., The Protean Ass: The 'Metamorphoses' of Apuleius from Antiquity to the Renaissance (Oxford: Oxford University Press, 2007)

Cavanagh, Sheila T., Wanton Eyes and Chaste Desires: Female Sexuality in 'The Faerie Queene' (Bloomington and Indianapolis: Indiana University Press, 1994)

Cazamian, Louis, The Development of English Humor (Durham, NC: Duke University Press, 1952)

Cheney, Donald, Spenser's Image of Nature (New Haven: Yale University Press, 1966)

Cheney, Donald, 'Spenser's Parody', Connotations, 12 (2002), 1-13

Church, R. W., Spenser, 2nd edn (London: Macmillan, 1888)

Clark, Judith Petterson, 'His Earnest unto Game: Spenser's Humor in The Faerie Queene', Emporia State Research Studies, 15 (1967), 13-24, 26-7

Coles, Kimberly Anne, " "Perfect hole”: Elizabeth I, Spenser, and Chaste Productions, ELR, 32 (2002), 31-61

Cooper, Helen, The English Romance in Time: Transforming Motifs from Geoffrey of Monmouth to the Death of Shakespeare (Oxford: Oxford University Press, 2004)

Cooper, Helen, Shakespeare and the Middle Ages: An Inaugural Lecture Delivered at the University of Cambridge, April 2005 (Cambridge: Cambridge University Press, 2006)

Cormier, Raymond, 'Humour in the Roman d'Eneas', Florilegium, 7 (1985), 129-44 
Corrigan, Robert W., ed., Comedy: A Critical Anthology (Boston, MA: Houghton Mifflin, 1971)

Craig, Martha, 'The Secret Wit of Spenser's Language', in Elizabethan Poetry: Modern Essays in Criticism, ed. Paul J. Alpers (New York: Oxford University Press, 1967), pp. 447-72

Cross, Claire, The Royal Supremacy in the Elizabethan Church (London: Allen \& Unwin, 1969)

Delany, Sheila, 'The Logic of Obscenity in Chaucer's Legend of Good Women', Florilegium, 7 (1985), 189-205

Dillon, Janette, 'Elizabethan Comedy', in The Cambridge Companion to Shakespearean Comedy, ed. Alexander Leggatt (Cambridge: Cambridge University Press, 2002), pp. 47-63

Dinshaw, Carolyn, Chaucer's Sexual Poetics (Madison: University of Wisconsin Press, 1989)

Dodge, R. E. N., 'Spenser's Imitations from Ariosto', PMLA, 12 (1897), 151-204

Duffy, Eamon, The Stripping of the Altars: Traditional Religion in England c. 1400-c. 1580 (New Haven: Yale University Press, 1992)

Dundas, Judith, “"Muiopotmos": A World of Art', Yearbook of English Studies, 5 (1975), 30-8

Eastman, Max, Enjoyment of Laughter (London: Hamish Hamilton, 1937) Eco, Umberto, The Name of the Rose (London: Minerva, 1992)

Edwards, Michael, 'A Meaning for Mock-Heroic', Yearbook of English Studies, 15 (1985), 48-63

Elias, Norbert, The History of Manners, trans. Edmund Jephcott (Oxford: Blackwell, 1978)

Erickson, Wayne, 'The Poet's Power and the Rhetoric of Humility in Spenser's Dedicatory Sonnets', SLI, 38 (2005), 91-118

Esolen, Anthony M., 'Irony and the Pseudo-Physical in The Faerie Queene', SSt, 8 (1987), 61-78

Esolen, Anthony M., 'The Disingenuous Poet Laureate: Spenser's Adoption of Chaucer', SP, 87 (1990), 285-311

Esolen, Antony M., 'Highways and Byways: A Response to Donald Cheney', Connotations, 13 (2003), 1-4

Evans, Robert O., 'Spenserian Humor: Faerie Queene III and IV', Neuphilologische Mitteilungen, 60 (1959), 288-99

Farnham, Willard, 'The Medieval Comic Spirit in the English Renaissance', in Joseph Quincy Adams Memorial Studies, ed. James G. McManaway et al. (Washington, D.C.: Folger Shakespeare Library, 1948), pp. 429-37

Fish, Stanley, Surprised by Sin: The Reader in 'Paradise Lost' (Basingstoke: Macmillan, 1997) 
Foster, Verna A., The Name and Nature of Tragicomedy (Aldershot: Ashgate, 2004)

Freeman, Louise Gilbert, 'Vision, Metamorphosis, and the Poetics of Allegory in the Mutabilitie Cantos', SEL, 45 (2005), 65-93

Freud, Sigmund, Art and Literature, Penguin Freud Library, 14 (London: Penguin, 1990)

Froude, James A. History of England, 10 vols (London: Parker, Son, and Bourn, 1862-6), Vol. II, retrieved from https://babel.hathitrust.org/ cgi/pt?id=hvd.hw20o3;view=1 up;seq=6 (accessed May 2019)

Frye, Northrop, Anatomy of Criticism: Four Essays (Princeton: Princeton University Press, 1957)

Frye, Northrop, Northrop Frye's Notebooks on Renaissance Literature, ed. Michael Dolzani, Collected Works of Northrop Frye, 20 (Toronto: University of Toronto Press, 2006)

Fudge, Erica, 'Learning to Laugh: Children and Being Human in Early Modern Thought', Textual Practice, 17 (2003), 277-94

Gaisser, Julia Haig, The Fortunes of Apuleius and the 'Golden Ass': A Study in Transmission and Reception (Princeton: Princeton University Press, 2008)

Gibbs, Donna, Spenser's 'Amoretti': A Critical Study (Aldershot: Scholar Press, 1990)

Gilbert, Allan H., 'Spenserian Comedy', Tennessee Studies in Literature, 2 (1957), 95-104

Groves, Beatrice, 'The Redcrosse Knight and "The George"', SSt, 25 (2010), 371-6

Gurevich, Aron, Medieval Popular Culture: Problems of Belief and Perception, trans. János M. Bak and Paul A. Hollingsworth (Cambridge: Cambridge University Press, 1988)

Hackett, Helen, Virgin Mother, Maiden Queen: Elizabeth I and the Cult of the Virgin Mary (Basingstoke: Macmillan, 1995)

Hadfield, Andrew, 'Spenser and Jokes', SSt, 25 (2010), 1-19

Hadfield, Andrew, 'Spenser and Religion - Yet Again', SEL, 51 (2011), 21-46

Hamilton, A. C., ed., The Spenser Encyclopedia (Toronto: University of Toronto Press, 1990)

Hardin, Richard F., 'Spenser's Aesculapius Episode and the English Mummers' Play', SSt, 15 (2001), 251-3

Hecht, Paul J., 'Letters for the Dogs: Chasing Spenserian Alliteration', SSt, 25 (2010), 263-85 
Heiges Blythe, Joan, 'Spenser and the Seven Deadly Sins: Book I, Cantos IV and V', ELH, 39 (1972), 342-52

Helgerson, Richard, The Elizabethan Prodigals (Berkeley: University of California Press, 1976)

Hendrix, Laurel, " "Mother of laughter, and welspring of blisse": Spenser's Venus and the Poetics of Mirth', ELR, 23 (1993), 113-33

Herrick, Marvin T., Comic Theory in the Sixteenth Century (Urbana: University of Illinois Press, 1964 [1950])

Higgins, Anne, 'Spenser Reading Chaucer: Another Look at the Faerie Queene Allusions', JEGP, 89 (1990), 17-36

Hillman, David, Shakespeare's Entrails: Belief, Scepticism, and the Interior of the Body (Basingstoke: Palgrave Macmillan, 2007)

Hoffman, Donald L., 'Malory and the English Comic Tradition', in Arthurian Literature XIX: Comedy in Arthurian Literature, ed. Keith Busby and Roger Dalrymple (Cambridge: D. S. Brewer, 2003), pp. 177-88.

Holcomb, Chris, Mirth Making: The Rhetorical Discourse on Jesting in Early Modern England (Columbia: University of South Carolina Press, 2001)

Hopkins, David, 'Dryden and Ovid's "Wit out of Season"', in Ovid Renewed: Ovidian Influences on Literature and Art from the Middle Ages to the Twentieth Century, ed. Charles Martindale (Cambridge: Cambridge University Press, 1988), pp. 167-90

Hough, Graham, Preface to 'The Faerie Queene' (London: Duckworth, 1983 [1962])

Huizinga, J[ohan], Homo ludens: A Study of the Play-Element in Culture (London: Routledge \& Kegan Paul, 1980 [1949])

Huston, J. Dennis, 'The Function of the Mock Hero in Spenser's "Faerie Queene", $M P, 66$ (1969), 212-17

Jacobson, Howard, Seriously Funny: From the Ridiculous to the Sublime (London: Penguin, 1997)

Javitch, Daniel, Proclaiming a Classic: The Canonization of 'Orlando furioso' (Princeton: Princeton University Press, 1991)

Javitch, Daniel, 'The Advertising of Fictionality in Orlando furioso' in Ariosto Today: Contemporary Perspectives, ed. Donald Beecher et al. (Toronto: University of Toronto Press, 2003), pp. 106-25

Johnson, Paul, Elizabeth I: A Study in Intellect and Power (London: Weidenfeld and Nicolson, 1974)

Jones, Richard Foster, The Triumph of the English Language (Stanford: Stanford University Press, 1953) 
Kahrl, Stanley J., 'The Medieval Origins of the Sixteenth-Century English Jest-Books', Studies in the Renaissance, 13 (1966), 166-83

Kaske, Carol, 'Review of Harold W. Weatherby, Mirrors of Celestial Grace: Patristic Theology in Spenser's Allegory', SN, 26 (1995), 15-19

Kaula, David, 'The Low Style in Nashe's The Unfortunate Traveller', SEL, 6 (1966), 43-57

Kay, Sarah, 'Courts, Clerks, and Courtly Love', in The Cambridge Companion to Medieval Romance, ed. Roberta L. Krueger (Cambridge: Cambridge University Press, 2000), pp. 81-96

Keach, William, 'Verbal Borrowing in Elizabethan Poetry: Plagiarism or Parody?', Centrum, 4 (1976), 21-31

Keach, William, Elizabethan Erotic Narratives: Irony and Pathos in the Ovidian Poetry of Shakespeare, Marlowe, and Their Contemporaries (New Brunswick: Rutgers University Press, 1977).

King, Andrew, 'The Faerie Queene' and Middle English Romance: The Matter of Just Memory (Oxford: Clarendon Press, 2000)

King, Andrew, 'Spenser, Chaucer, and Medieval Romance', in The Oxford Handbook of Edmund Spenser, ed. Richard A. McCabe (Oxford: Oxford University Press, 2010), pp. 553-72

King, John, 'Spenser's Religion', in The Cambridge Companion to Spenser, ed. Andrew Hadfield (Cambridge: Cambridge University Press, 2001), pp. $200-16$

King, Ros, 'In Lieu of Democracy; or, How Not to Lose Your Head: Theatre and Authority in Renaissance England', in Early Modern Tragicomedy, ed. Subha Mukherji and Raphael Lyne (Cambridge: D. S. Brewer, 2007), pp. 84-100

Kolve, V. A., The Play Called Corpus Christi (London: Edward Arnold, 1966)

Krier, Theresa M., Gazing on Secret Sights: Spenser, Classical Imitation, and the Decorums of Vision (Ithaca and London: Cornell University Press, 1990)

Kucich, Greg, 'The Duality of Romantic Spenserianism', SSt, 8 (1987), 287-307

Lamb, Mary Ellen, 'The Red Crosse Knight, St George, and the Appropriation of Popular Culture', SSt, 18 (2003), 185-208

Lamb, Mary Ellen, The Popular Culture of Shakespeare, Spenser and Jonson (Abingdon: Routledge, 2006)

Lehnhof, Kent R., 'Incest and Empire in The Faerie Queene', ELH, 73 (2006), 215-43 
Leonard, Frances McNeely, Laughter in the Courts of Love: Comedy in Allegory from Chaucer to Spenser (Oklahoma: Pilgrim, 1981)

Lethbridge, J. B., 'The Poetry of The Faerie Queene', in Spenser in the Moment, ed. Paul J. Hecht and J. B. Lethbridge (Madison, NJ: Fairleigh Dickinson University Press, 2015), pp. 169-216

Levin, Richard, 'The Legende of the Redcrosse Knight and Una; or, Of the Love of a Good Woman', SEL, 31 (1991), 1-24

Lewis, C. S., The Discarded Image: An Introduction to Medieval and Renaissance Literature (Cambridge: Cambridge University Press, 1970 [1967])

Lewis, C. S., The Allegory of Love (Oxford: Oxford University Press, 1979 [1936])

Lindvall, Terry, 'Toward a Divine Comedy: A Plagiarized History, Theology and Physiology of Christian Faith and Laughter', Lamp-Post of the Southern California C. S. Lewis Society, 27 (2003), 12-31

Mack, Maynard, 'The Second Shepherds' Play: A Reconsideration', PMLA, 93 (1978), 78-85

Martin, Adrienne, 'Humor and Violence in Cervantes', in The Cambridge Companion to Cervantes (Cambridge: Cambridge University Press, 2002), pp. 160-85

Martin, Carol, A. N., 'Authority and the Defense of Fiction: Renaissance Poetics and Chaucer's House of Fame', in Refiguring Chaucer in the Renaissance, ed. Theresa M. Krier (Gainesville: University Press of Florida), pp. 40-65

Martz, Louis L., 'The Amoretti: "Most Goodly Temperature", in Form and Convention in the Poetry of Edmund Spenser, ed. William Nelson (New York: Columbia University Press, 1961), pp. 146-68

Mason, H. A., To Homer through Pope: An Introduction to Homer's 'Iliad' and Pope's Translation (London: Chatto \& Windus, 1972)

McCabe, Richard A., 'Ireland: Policy, Poetics and Parody', in The Cambridge Companion to Spenser, ed. Andrew Hadfield (Cambridge: Cambridge University Press, 2001), pp. 60-78

McCabe, Richard A., Spenser's Monstrous Regiment: Elizabethan Ireland and the Poetics of Difference (Oxford: Oxford University Press, 2002)

McCabe, Richard A., 'Parody, Sympathy and Self: A Response to Donald Cheney', Connotations, 13 (2003), 5-22

McFaul, Tom, 'The Butterfly, the Fart and the Dwarf: The Origins of the English Laureate Micro-Epic', Connotations, 17 (2007/8), 144-64 
McKnight, George H., Middle English Humorous Tales in Verse (New York: AMS Press, 1972 [1913])

Miller, David Lee, The Poem's Two Bodies: The Poetics of the 1590 'Faerie Queene' (Princeton: Princeton University Press, 1988)

Miller, David Lee, 'Laughing at Spenser's Daphnaida', SSt, 26 (2011), 241-50

Miller, Henry Knight, 'The Paradoxical Encomium with Special Reference to Its Vogue in England, 1600-1800', MP, 53 (1956), 145-78

Miller, Lewis H., Jr, 'The Ironic Mode in Books 1 and 2 of The Faerie Queene', PLL, 7 (1971), 133-49

Montrose, Louis, 'Spenser and the Elizabethan Political Imaginary', ELH, 69 (2002), 907-46

Morreall, John, 'Philosophy of Humor', in The Stanford Encyclopedia of Philosophy Archive (Winter 2016 edn), ed. Edward N. Zalta, https://plato. stanford.edu/archives/win2016/entries/humor/ (accessed May 2019)

Murillo, L. A., 'Don Quixote as Renaissance Epic', in Cervantes and the Renaissance, ed. Michael D. McGaha (Easton, PA: Juan de la Cuesta, 1980), pp. 51-70

Nadal, T. W., 'Spenser's Muiopotmos in Relation to Chaucer's Sir Thopas and The Nun's Priest's Tale, PMLA, 25 (1910), 640-56

Nelson, William, The Poetry of Edmund Spenser: A Study (New York: Columbia University Press, 1963)

Nelson, William, Fact or Fiction: The Dilemma of the Renaissance Storyteller (Cambridge, MA: Harvard University Press, 1973)

Nietzsche, Friedrich, Beyond Good and Evil, trans. R. J. Hollingdale (London: Penguin, 2003)

Nohrnberg, James, The Analogy of 'The Faerie Queene' (Princeton: Princeton University Press, 1976)

Norbrook, David, Poetry and Politics in the English Renaissance, rev. edn (Oxford: Oxford University Press, 2002)

Nuttall, A. D., 'Spenser and Elizabethan Alienation', Essays in Criticism, 55 (2005), 209-25

O'Callaghan, Michelle, 'Spenser's Literary Influence', in The Oxford Handbook of Edmund Spenser, ed. Richard A. McCabe (Oxford: Oxford University Press, 2010), pp. 664-83

Oram, William A., 'Spenser's Audiences, 1589-91', SP, 100 (2003), 514-33

Oram, William A., 'Human Limitation and Spenserian Laughter', SSt, 30 (2015), 35-56

Orange, Linwood E., ' "All Bent to Mirth": Spenser's Humorous Wordplay', SAQ, 71 (1972), 539-47 
Orgel, Stephen, 'Spenser from the Gutters to the Margins: An Archeology of Reading', in The Construction of Textual Identity in Medieval and Early Modern Literature, ed. Indira Ghose and Denis Renevey, Swiss Papers in English Language and Literature, 22 (Tübingen: Narr, 2009), pp. 125-41

Parker, Patricia, Inescapable Romance: Studies in the Poetics of a Mode (Princeton: Princeton University Press, 1979)

Partridge, Eric, Shakespeare's Bawdy, 3rd edn (London: Routledge, 1990 [1968])

Peter, John, A Critique of 'Paradise Lost' (New York: Columbia University Press, 1960)

Pheifer, J. D., 'Errour and Echidna in The Faerie Queene: A Study in Literary Tradition', in Literature and Learning in Medieval and Renaissance England, ed. John Scattergood (Dublin: Irish Academic Press, 1984), pp. 127-74

Pieper, Josef, Leisure: The Basis of Culture, trans. Alexander Dru (London: Faber and Faber, 1952)

Potkay, Adam, 'Spenser, Donne, and the Theology of Joy', SEL, 46 (2006), 43-66.

Prescott, Anne Lake, 'Humour and Satire in the Renaissance', in The Cambridge History of Literary Criticism: The Renaissance, ed. Glyn Norton (Cambridge: Cambridge University Press, 1999), pp. 284-91

Pugh, Syrithe, Spenser and Ovid (Aldershot: Ashgate, 2005)

Pugh, Syrithe, 'Acrasia and Bondage: Guyon's Perversion of the Ovidian Erotic in Book II of The Faerie Queene', in Edmund Spenser: New and Renewed Directions, ed. J. B. Lethbridge (Madison, NJ: Fairleigh Dickinson University Press, 2006), pp. 153-94

Pugh, Syrithe, 'Reinventing the Wheel: Spenser's "Virgilian Career"', in Spenser in the Moment, ed. Paul J. Hecht and J. B. Lethbridge (Madison, NJ: Fairleigh Dickinson University Press, 2015), pp. 3-34

Quilligan, Maureen, Milton's Spenser: The Politics of Reading (Ithaca and London: Cornell University Press, 1983)

Quilligan, Maureen, 'The Comedy of Female Authority in The Faerie Queene', ELR, 17 (1987), 151-71

Ramachandran, Ayesha, 'Clarion in the Bower of Bliss: Poetry and Politics in Spenser's "Muiopotmos", SSt, 20 (2005): 77-106

Rasmussen, Mark David, 'Complaints and Daphnaida (1591)', in The Oxford Handbook of Edmund Spenser, ed. Richard A. McCabe (Oxford: Oxford University Press, 2010), pp. 218-36 
Rhu, Lawrence F., 'Romancing Eliza: The Political Decorum of Ariostan Imitation in The Faerie Queene', Renaissance Papers (1993), 31-9

Rhu, Lawrence F., 'On Cheney on Spenser's Ariosto', Connotations, 15 (2005), 91-6

Richard, Terry, “"Meaner Themes”: Mock-Heroic and Providentialism in Cowper's Poetry', SEL, 34 (1994), 617-34

Risden, E. L., 'Heroic Humor in Beowulf', in Humour in Anglo-Saxon Literature, ed. Jonathan Wilcox (Cambridge: D. S. Brewer, 2000), pp. $71-8$

Robin, Diana, 'Review of David Marsh, Lucian and the Latins: Humor and Humanism in the Early Renaissance', RQ, 53 (2003), 559-60

Sanders, Andrew, The Short Oxford History of English Literature, 3rd edn (Oxford: Oxford University Press, 2004)

Screech, M. A., Laughter at the Foot of the Cross (London: Penguin, 1997)

Screech, M. A., and Ruth Calder, 'Some Renaissance Attitudes to Laughter', in Humanism in France, ed. A. H. T. Levi (Manchester: Manchester University Press, 1970), pp. 216-28

Sehmby, Dalbir, 'Comic Nescience: An Experimental View of Humour and a Case for the Cultural Negotiation Function of Humour', in Developments in Linguistic Humour Theory, ed. Marta Dynel (Amsterdam: John Benjamins, 2013), pp. 75-102

Shroeder, John W., 'Spenser's Erotic Drama: The Orgoglio Episode', ELH, 29 (1962), 140-59

Silberman, Lauren, 'Spenser and Ariosto: Funny Peril and Comic Chaos', Comparative Literature Studies, 25 (1988), 23-34

Smuts, Aaron, 'Humor', in Internet Encyclopedia of Philosophy, https:// iep.utm.edu/humor/\#SH2a (accessed May 2019)

Solomon, Robert, 'Are the Three Stooges Funny? Soitanly!', in Ethics and Values in the Information Age, ed. Joel Rudinow and Anthony Graybosch (Belmont, CA: Wadsworth, 2002), pp. 604-10

Stallybrass, Peter, and Allon White, The Politics and Poetics of Transgression (London: Methuen, 1986)

Steinberg, Glenn A., 'Spenser's Shepheardes Calender and the Elizabethan Reception of Chaucer', ELR, 35 (2005), 31-51

Steinberg, Glenn A., 'Chaucer's Mutability in Spenser's Mutabilitie Cantos', SEL, 46 (2006), 27-42

Stephens, Dorothy, 'Spenser's Language(s): Linguistic Theory and Poetic Diction', in The Oxford Handbook of Edmund Spenser, ed. Richard A. McCabe (Oxford: Oxford University Press, 2010), pp. 367-84 
Sterne, Virginia F., Gabriel Harvey: A Study of His Life, Marginalia, and Library (Oxford: Clarendon Press, 1979)

Strong, Roy, The Cult of Elizabeth: Elizabethan Portraiture and Pageantry (London: Thames and Hudson, 1977)

Sullivan, Garrett, and Linda Woodbridge, 'Popular Culture in Print', in The Cambridge Companion to English Literature, 1500-1600, ed. Arthur F. Kinney (Cambridge: Cambridge University Press, 2000), pp. 265-86

Suttie, Paul, 'Edmund Spenser's Political Pragmatism', SP, 95 (1998), 56-76 Thomas, Keith, 'The Place of Laughter in Tudor and Stuart England', TLS, 21 (1977), 77-81

Tigges, Wim, 'Romance and Parody', in Companion to Middle English Romance, ed. Henk Aertsen and Alasdair A. MacDonald (Amsterdam: VU University Press, 1990), pp. 129-51

Tilley, M. P. A Dictionary of the Proverbs in England in the Sixteenth and Seventeenth Centuries (Ann Arbor: University of Michigan Press, 1950)

Trigg, Stephanie, 'Chaucer's Influence and Reception', in The Yale Companion to Chaucer, ed. Seth Lerer (New Haven: Yale University Press, 2006), pp. 297-323

Tuell, Anne Kimball, 'Note on Spenser's Clarion', Modern Language Notes, 36 (1921), 182-3

Tuve, Rosemond, Allegorical Imagery: Some Medieval Books and Their Posterity (Princeton: Princeton University Press, 1966)

Vaught, Jennifer C., 'Spenser's Dialogic Voice in Book I of The Faerie Queene', SEL, 41 (2001), 71-89

Vaught, Jennifer C., 'The Mummers' Play St George and the Fiery Dragon and Book I of Spenser's Faerie Queene', LATCH, 3 (2010), 85-106

Villeponteaux, Mary, "Not as women wonted be": Spenser's Amazon Queen', in Dissing Elizabeth: Negative Representations of Gloriana, ed. Julia M. Walker (Durham, NC: Duke University Press, 1998), pp. 209-25

Walls, Kathryn, 'The "Cupid and Psyche" Fable of Apuleius and Guyon's Underworld Adventure in The Faerie Queene II.vii.3-viii.8', SSt, 26 (2011), 45-73.

Walls, Kathryn, God's Only Daughter: Spenser's Una as the Invisible Church (Manchester: Manchester University Press, 2013)

Walls, Kathryn, 'Spenser and the "Medieval" Past', in Spenser in the Moment, ed. Paul J. Hecht and J. B. Lethbridge (Madison, NJ: Fairleigh Dickinson University Press, 2015), pp. 35-66 
Watkins, W. B. C., Shakespeare and Spenser (Princeton: Princeton University Press, 1950)

Weinberg, Bernard, A History of Literary Criticism in the Italian Renaissance, 2 vols (Chicago: University of Chicago Press, 1961)

Weiss, Judith, "“The Courteous Warrior”: Epic, Romance and Comedy in Boeve de Haumtone', in Boundaries in Medieval Romance, ed. Neil Cartlidge (Cambridge: D. S. Brewer, 2008), pp. 149-60

West, Michael, 'Spenser's Art of War: Chivalric Allegory, Military Technology, and the Elizabethan Mock-Heroic Sensibility', RQ, 41 (1988), 654-704

Wiggens, Peter DeSa, 'Spenser's Use of Ariosto: Imitation and Allusion in Book I of The Faerie Queene', RQ, 44 (1991), 257-79

Wilson-Okamura, David Scott, Spenser's International Style (Cambridge: Cambridge University Press, 2013)

Wofford, Susanne Lindgren, 'Gendering Allegory: Spenser's Bold Reader and the Emergence of Character in The Faerie Queene III', Criticism, 30 (1988), $1-21$

Wolfe, Jessica, 'Chapman's Ironic Homer', College Literature, 35 (2008), 151-86

Wood, Rufus, Metaphor and Belief in 'The Faerie Queene' (Basingstoke: Macmillan, 1997)

Woodcock, Matthew, Fairy in 'The Faerie Queene': Renaissance ElfFashioning and Elizabethan Myth-Making (Aldershot: Ashgate, 2004) 